\title{
PEMBERDAYAAN KELOMPOK TANI DALAM PENGEMBANGAN USAHA KOMPOS DI KECAMATAN GERAGAI
}

\author{
Yurleni dan Adriani \\ Fakultas Peternakan Universitas Jambi bekerjasama dengan CSR PetroChina International Jabung Ltd \\ Jln Raya Jambi - Muaro Bulian KM. 15 Mendalo Indah Jambi 36122 \\ yurleni_fapet@unja.ac.id
}

\begin{abstract}
Abstrak
Tujuan kegiatan adalah pemberdayaan kelompok tani dalam mengolah limbah peternakan dan limbah kelapa sawit menjadi kompos di Kecamatan Geragai. Kegiatan dilakukan di Kelompok Tani Karya Muda Desa Pandan Sejahtera Kecamatan Geragai Kabupaten Tanjung Jabung Timur. Kelompok ini memiliki 15 ekor sapi secara swadaya dan kebun kelapa sawit seluas 52 ha, dengan anggota sebanyak 26 orang. Kelompok tani ini baru berdiri dan belum memiliki sarana dan prasarana pengolahan kompos. Metode kegiatan meliputi: 1) Koordinasi, 2) pelatihan teknis, 3) study banding dan 4) melengkapai sarana dan prasarana. Pelatihan teknis pengolahan limbah menjadi kompos dilakukan selama 2 hari bertempat di Taman Teknologi Pertanian (TTP) Geragai diikuti 30 peserta. Kegiatan study banding berkunjung ke kelompok tani Karya Trans Mandiri desa Dataran Kempas. Sarana dan prasarana pengolahan kompos berupa rumah kompos, chopper, cultivator, mesin jahit karung, angkong dan bahan baku pembuatan kompos untuk 10 ton. Hasil yang diperoleh adalah pada tahap awal kegiatan sudah diolah kompos sebanyak 5 ton. Hasil monitoring dan evaluasi pelatihan didapatkan bahwa pelatihan ini "sesuai" dan "sangat sesuai" dengan kebutuhan kelompok dalam pengembangan usaha yang dilakukan baik materi, contoh, praktek maupun diskusi yang dilakukan. Kesimpulan dari monitoring dan evaluasi akhir kegiatan dengan cara diskusi didapatkan bahwa kegiatan ini bisa diterapkan dan akan dikembangkan menjadi usaha utama kelompok terutama produksi kompos, selain itu dipertimbangkan pengembangan usaha kearah integrated farming system. Sehingga kedepan bisa menjadi salah satu pusat percontohan dan pelatihan di Kabupaten Tanjung Jabung Timur.
\end{abstract}

Kata Kunci : Kompos, sawit, integrasi usaha tani, pemberdayaan

\section{PENDAHULUAN}

\subsection{Latar Belakang}

Kecamatan Geragai merupakan salah satu kecamatan yang ada di kabupaten Tanjung Jabung Timur, Kecamatan ini memiliki 9 desa dan kelurahan diantaranya Desa Pandan Sejahtera. Desa ini berpotensi sebagai penghasil kompos dari limbah peternakan dan limbah pertanian.

Kelompok ini merupakan kelompok tani yang baru dibentuk oleh masyarakat yang ada di Desa Pandan Sejahtera, dengan fokus kegiatan peternakan sapi dan kebun kelapa sawit. Kelompok ini sudah memiliki 15 ekor sapi secara swadaya yang dipelihara pada kandang koloni (kandang kelompok) dan kebun kelapa sawit seluas 52 ha. Sitem pemeliharaan sapi dilakukan secara ekstensif dan pemeliharaannya dilakukan secara bergantian (piket). Kelompok ini memiliki anggota sebanyak 26 orang yang umumnya adalah generasi muda.

Komunikasi tahap awal dengan anggota kelompok tani Karya Muda didapat informasi bahwa kelompok tani cukup serius dalam pemeliharaan sapi dan mengelola kebun kelapa sawit. Kondisi ini terlihat dari aktivitas yang sudah dilakukan yaitu: 1) sudah ada kandang kelompok dan ternak sapi secara swadaya, 2) sudah memiliki kebun kelapa sawit

$$
\text { Ekonomi, Sosial, dan Budaya }
$$




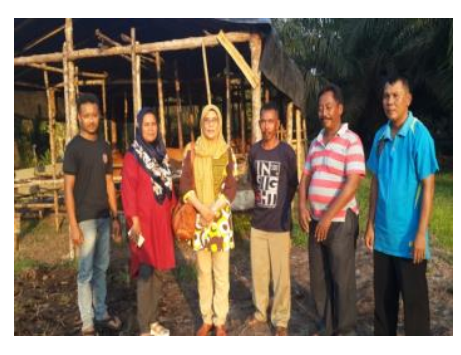

seluas 52 ha, 3) sudah menanam rumput unggul berupa rumput gajah (Pennisetum purpureum) untuk pakan ternak sapi seluas kurang lebih 4 ha disekitar kebun sawit dan disepanjang kanal dekat rumah anggota kelompak. Sekarang kelompok tani sedang mempersiapkan penanaman indigofera sebagai salah satu sumber pakan ternak berkualitas.

Kelompok Tani Karya Muda ini mempunayi potensi yang cukup baik untuk berkembang karena 1) pengurus kelompok masih muda dan terdapat 2 orang sarjana dalam kepengurusan, 2) luas lahan yang disediakan untuk usaha peternakan sekitar 6 ha di bawah kebun kelapa sawit, 3) lokasi kandang berada dipinggir jalan desa. Pengurus kelompok yang masih muda sangat memudahkan dalam transfer teknologi tepat guna (TTG) dan lebih mudah dalam introduksi inovasi baru, namun pada sisi lain karena kelompok tani ini masih baru maka potensi bahan baku yang dimiliki kelompok masih terbatas terutama feces sapi. Jumlah sapi sebanyak 15 ekor akan tersedia feces sekitar $150 \mathrm{~kg} / \mathrm{hari}$ atau bisa memanfaatkan feces yang ada di desa Pandan Sejahtera dengan populasi sapi sebesar 430 ekor

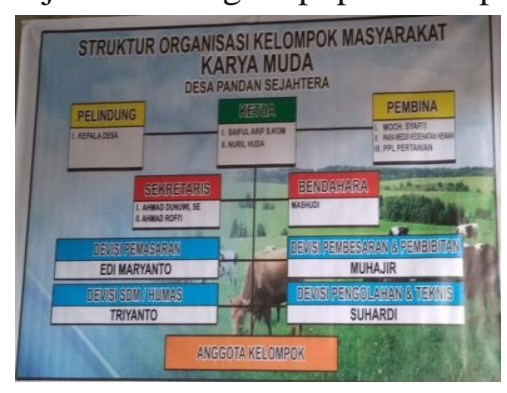
akan tersedia feces sebesar $4.300 \mathrm{~kg} / \mathrm{hari}$. Bahan baku kompos lainnya adalah pelepah kelapa sawit, tangkos (tandan kosong kelapa sawit), fiber dari kelapa sawit dan abu boiler pabrik kelapa sawit.

Limbah pelepah sawit tersedia banyak pada kelompok yaitu dengan luas lahan anggota kelompok 52 ha akan tersedia limbah pelepah sebesar 15.392 $\mathrm{kg} /$ hari. Limbah pabrik sawit juga ada di kecamatan Geragai berupa tandan kosong, fiber dan abu boiler. Semua ini bisa dimanfaatkan sebagai bahan campuran dalam pembuatan kompos.

Namun kelemahannya kelompok ini adalah 1) Kelompok tani baru terbentuk, 2) belum memiliki peralatan produksi, 3) sistem pemeliharan sapi masih secara ekstensif. Untuk melakukan aktifitas produksi kompos sangat diperlukan dukungan sarana dan prasarana produksi, pelatihan dan promosi produk untuk pemasaran. Pemanfaatan feces sapi sebagai bahan baku kompos diharapkan merubah pola pemeliharan dari ekstensif menjadi intensif

Untuk optimalisasi usaha pada kedua kelompok tani ini, maka kegiatan diseuaikan dengan kebutuhan dan potensi yang dimiliki. Sehingga usaha yang sudah ada memberi nilai tambah bagi ekonomi anggota kelompok dan masyarakat pada umumnya.

Berdasarakan kondisi yang ada, maka kelompok tani Karya Muda mengusulkan pendanaan untuk kegiatan dimaksud kepada PetroChina International Jabung Ltd (PCJL) melalui kegiatan dana CSR (Corporate Social Responsibility) yaitu kegiatan "Pemberdayaan Kelompok Tani Dalam Pengembangan Usaha Kompos Di Kecamatan Geragai”.

\subsection{Tujuan Kegiatan}

1. Meningkatkan pengetahuan dan keterampilan anggota kelompok tani dalam mengelola limbah menjadi kompos

2. Diffusi dan pemanfaatan teknologi tepat guna (TTG) dalam upaya peningkatan nilai tambah (value added) limbah

\section{METODE}

Pelaksanaan kegiatan meliputi: 1) Koordinasi dengan kelompok tani, Dinas Perkebunan dan Peternakan Kabupaten Tanjung Jabung Barat, PetroChina International Jabung Ltd, 2) Pelatihan teknis pengolahan limbah menjadi kompos, 3) Studi banding, 4) Melengkapi sarana dan prasarana pengolahan kompos.

Koordinasi yang dilakukan dengan anggota kelompok yaitu tentang rencana detil kegiatan yang akan dilakukan terutama mengenai lokasi pembuatan rumah kompos, teknis pelaksanaan pelatihan dan study banding.

Koordinasi dengan Dinas Perkebunan dan Peternakan Tanjung Jabung Timur adalah sinkronisasi kegiatan dengan Dinas Perkebunan dan Peternakan dan rencana penggunaan fasilitas yang ada di TTP untuk pelaksanaan pelatihan.

Kegiatan koordinasi dengan PetroChina International Jabung Ltd. yaitu mengenai detil

$$
\text { Ekonomi, Sosial, dan Budaya }
$$


kegiatan yang akan dilakukan, teknis pelaksanaan kegiatan dan peserta yang akan dilibatkan dalam kegiatan pelatihan yaitu beberapa kelompok tani yang berada pada wilayah ring satu binaan PetroChina Intenational Jabung Ltd. diluar kelompok Tani Karya Muda.

Untuk mengetahui bahwa kegiatan ini berjalan dengan baik, maka akan dilakukan monitoring dari masing-masing tim yaitu PetroChina International Jabung Ltd, Tim Universitas Jambi, Tim Dinas Perkebunan dan Peternakan Kabupaten Tanjung Jabung Timur dan Tim TTP. Tujuannya adalah agar semua proses kegiatan yang sudah direncanakan berjalan sesuai dengan aturan yang ada dan sesuai harapan.

\section{HASIL DAN PEMBAHASAN}

\subsection{Koordinasi}

Kegiatan koordinasi diperlukan untuk pelaksanaan kegiatan secara besama-sama antara kelompok Tani Karya Muda, Dinas Perkebunan dan Peternakan Kabupaten

Tanjung Jabung Timur, Universitas Jambi, PetroChina International Jabung Ltd, Dinas Pemberdayaan Desa Kabupaten Tanjung

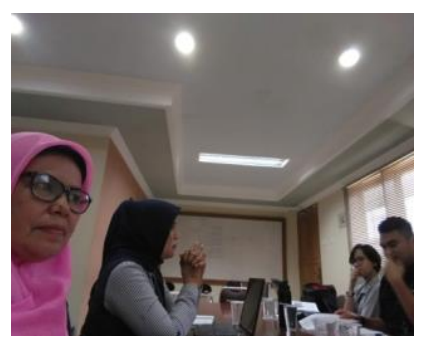

Jabung Timur, Taman Teknologi Pertanian (TTP), PPL (Petugas Penyuluh Lapangan). Tujuannya adalah untuk sinergivitas program yang dilakukan dengan semua pihak agar akselerasi pengembangan dan pemberdayaan kelompok tani bisa dilakukan.

Hasil diskusi dan koordinasi dengan kelompok tani disepakati lokasi pembuatan rumah kompos berada diseberang jalan dari posisi kandang sapi dengan jarak sekitar 200 meter. Lokasi ini berada pada lahan kelapa sawit milik pembina kelompok tani dengan luas 0,25 ha. Lokasi ini memungkinkan untuk dikembangkan menjadi sentra produksi kompos. Lokasi ini lebih tinggi, menghadap jalan yang berada disisi belakang dengan lebar 5 meter. Jalan masih berupa tanah tanpa pengerasan. Rencananya jalan ini dijadikan akses utama untuk aktivitas produksi kompos, namun penggunaan jalan perlu proses pengerasan. Sementara jalan lainnya yang bisa diakses untuk aktifitas produksi kompos adalah jalan desa yang posisinya pada bagian depan dari rumah kompos. Jalan ini merupakan jalan yang dipakai masyarakat desa dalam beraktivitas sehari-hari dan sudah diaspal.

Kegiatan koordinasi dengan Dinas Perkebunan dan Peternakan Kabupaten Tanjung Jabung Timur dan Taman Teknologi Pertanian Geragai adalah untuk pelatihan dilakukan di Taman Teknologi Pertanian, dengan menggunakan saung TTP. Praktek Pembuatan kompos, biourin dan pegolahan pakan dilakukan pada kandang dan rumah kompos milik TTP. Peserta yang diundang untuk kegiatan pelatihan ditambah beberapa kelompok tani yang berpotensi selain sasaran utama. Jumlah Ini disesuaikan dengan kondisi dan kebutuhan kegiatan.

Hasil koordinasi disepakati bahwa pelaksanaan kegiatan pelatihan dilakukan pada Taman Teknologi Pertanian kecamatan Geragai dan melibatkan beberapa kelompok tani yang berada pada wilayah ring satu binaan PetroChina intenational Jabung Ltd. diluar kelompok sasaran utama yaitu Koperasi Suka Maju dan kelompok Tani Karya Muda.

\section{Sedangkan}

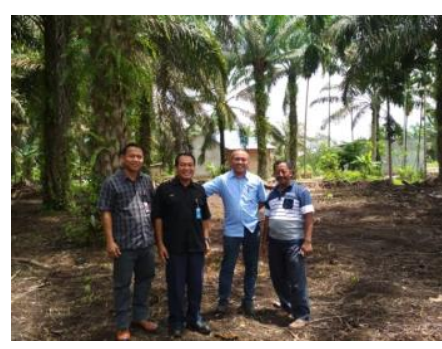

koordinasi dengan pihak PetroChina International Jabung Ltd menghasilkan kesepakatan bahwa pelaksanaan kegiatan melibatkan beberapa kelompok tani yang berada pada wilayah ring satu binaan PetroChina intenational Jabung Ltd. diluar kelompok sasaran utama yaitu Koperasi Suka Maju dan kelompok Tani Karya Muda.

\subsection{Pelatihan Teknis Pengolahan Limbah}

Sasaran utama kegiatan pelatihan teknis pengolahan limbah ternak dan limbah kelapa sawit untuk bahan kompos, biourin dan pakan ternak fermentasi adalah kelompok tani Karya Muda, dengan melibatkan beberapa kelompok tani lainnya sesuai dengan saran dan masukan dari Dinas Perkebunan dan peternakan Kabupaten Tanjung Jabung Timur, masukan dari PetroChina International Jabung Ltd. dan masukan dari Universitas Jambi. 
Kegiatan pelatihan dilakukan di Taman Teknologi Pertanian (TTP) Dinas Perkebunan dan Peternakan Kabupaten Tanjung Jabung Timur yang berlokasi di KTM (Kota Terpadu Mandiri) Kecamatan Geragai Kabupaten Tanjung Jabung Timur.

Pembukaan pelatihan teknis pengolahan limbah ternak dan limbah kelapa sawit dihadiri oleh kepala Dinas Perkebunan dan Peternakan Kabupaten Tanjung Jabung Timur, Koordinator TTP, Univesitas Jambi, BPTP

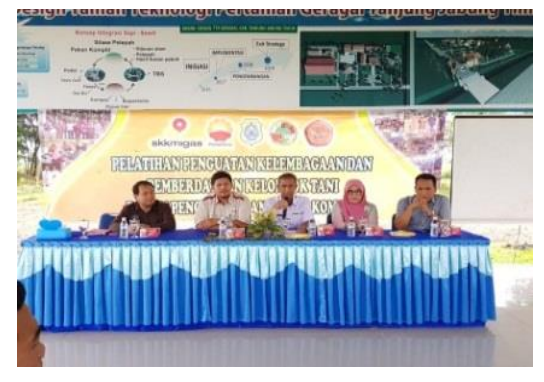
(Balain Pengkajian Teknologi Pertanian) provinsi Jambi, PT. WKS (Wira Karya Sakti), Camat kecamatan Geragai. Pembukaan acara pelatihan dilakukan oleh

Kepala Dinas Perkebunan dan Peternakan Kabupaten Tanjung Jabung Timur.

Pelatihan teknis pengolahan limbah ternak dan kelapa sawit dalam pembuatan kompos, pengolahan biourin dan pengolahan pakan ternak dilakukan selama 2 hari. Kegiatan ini diikuti

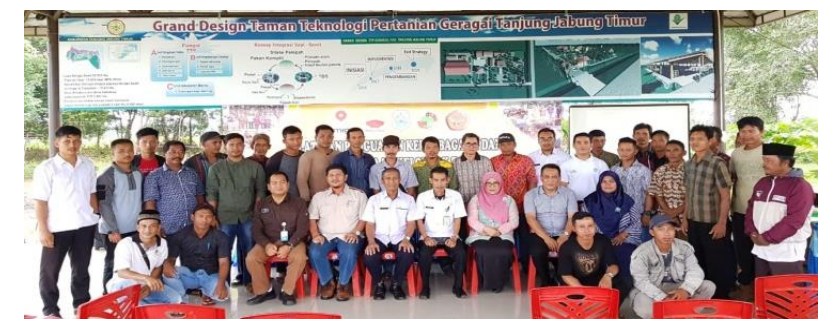

sebanyak 30 peserta yang terdiri dari 5 kelompok tani, dan utusan dari 3 desa yang ada di Kabupaten Tanjung Kabung Timur. Rincian perserta yang mengikuti pelatihan teknis pengolahan limbah dapat dilihat pada Tabel 1.

Peserta pelatihan yang paling banyak diikuti oleh kelompok tani Karya Muda, kondisi ini dikarenakan sasaran utama kegiatan pelatihan teknis pengolahan limbah ternak dan limbah kelapa sawit ini adalah kelompok tani Karya Muda.
Tabel 1. Peserta Pelatihan Tenis Pengolahan Limbah Ternak dan Kelapa Sawit

\begin{tabular}{|l|l|c|}
\hline No & $\begin{array}{l}\text { Nama Kelompok, Koperasi, } \\
\text { Utusan Desa }\end{array}$ & Peserta \\
\hline 1. & Kelompok Tani Karya Muda & 11 orang \\
\hline 2. & $\begin{array}{l}\text { Kelompok dari Dinas } \\
\text { Lingkungan Hidup }\end{array}$ & 3 orang \\
\hline 3. & $\begin{array}{l}\text { Taman Teknologi Pertanian } \\
\text { Geragai }\end{array}$ & 3 orang \\
\hline 4. & $\begin{array}{l}\text { Kelompok Tani Sumber } \\
\text { Rejeki }\end{array}$ & 3 orang \\
\hline 5. & Koperasi Suka Maju & 3 orang \\
\hline 6. & $\begin{array}{l}\text { Kelompok Tani Usaha } \\
\text { Mandiri }\end{array}$ & 4 orang \\
\hline 7. & Desa Teluk Dawan & 1 orang \\
\hline 8. & Desa Talang Babat & 1 orang \\
\hline 9. & Desa Pandan Lagan & 1 orang \\
\hline Jumlah & 30 Orang \\
\hline
\end{tabular}

Sementara kelompok tani lainnya yang mengikuti pelatihan ini merupakan kelompok yang berpotensi dalam pengembagan dan pengolahan kompos dari limbah ternak, limbah kelapa sawit dan limbah organik pasar. Ini sangat penting dilakukan untuk penyebarluasan informasi dan teknologi tepat guna (TTG) di masyarakat mengenai teknik pengolahan limbah menjadi kompos.

Kegiatan pelatihan ini melibatkan pemateri dari Dinas Perkebunan dan Peternakan Kabupaten Tanjung Jabung Timur mengenai kebijakan Dinas dalam integrasi sapi sawit, Universitas Jambi, Taman Teknologi Pertanian, BPTP (Balai Pengkajian Teknologi Pertanian) Jambi dan PT. WKS ( Wira Karya Sakti).
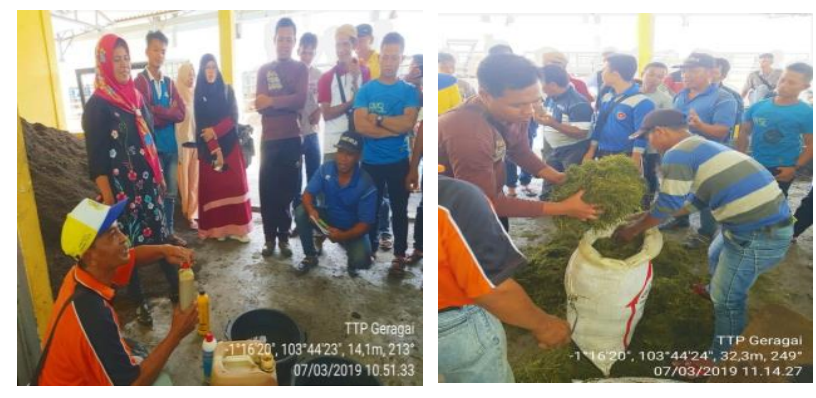

Untuk hari kedua kegiatan dilakukan praktek pembuatan kompos, pengolahan pakan ternak dan pengolahan biourin. 


\section{Study Banding Kelompok Tani Karya Muda}

Studi banding kelompok tani Karya Muda dilakukan pada kelompok tani Karya Trans Mandiri (KTM) Desa Dataran kempas kecamatan Tebing Tinggi. Pemilihan lokasi study banding ini karena ada aktivitas produksi kompos, kawasan ini juga terintegrasi dengan usaha peternakan kambing dan tanaman hultikultura (integrated farming system).

Tujuannya adalah untuk menambah wawasan, pengetahuan dan pengalaman anggota kelompok tani dalam mengelola usaha kompos, selain itu diharapkan kelompok tani Karya Muda terinspirasi

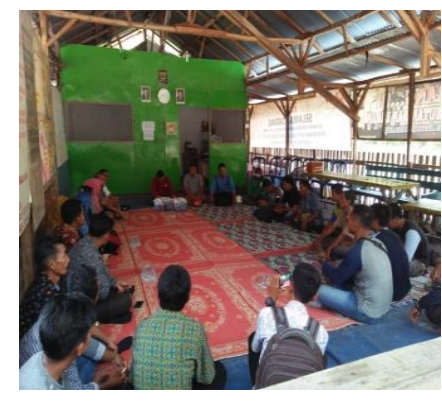
untuk mengembangkan usaha kelompoknya selain usaha kompos. Kegiatan pengolahan limbah, peternakan kambing dan tanaman hultikultura dalam satu kawasan seluas 2,5 ha pada kelompok tani KTM ini sangat menjanjikan dari segi pendapatan sehingga mengarah pada ekoagrowisata.

Kegiatan study banding ini diikuti sebanyak 15 orang peserta dari kelompok tani Karya Muda, didampingi oleh tim Universitas Jambi, Taman Teknologi Pertanian, Dinas Perkebunan dan Peternakan Kabupaten Tanjung Jabung Timur, PetroChina International Jabung Ltd, kepada Desa Dataran Kempas, Ketua Bumdes Desa Dataran Kempas.

Kegiatan study banding pada kelompok tani Karya Trans Mandiri dimulai dengan pembukaan dan pengarahan dari PetroChina International Jabung Ltd, Universitas Jambi, kemudian sukses story dari ketua kelompok tani Karya Trans Mandiri pak Ruskin. Selanjutnya dilakukan diskusi dengan semua peserta yang hadir .

Setelah kegiatan pengarahan dan penjelasan mengenai kegiatan yang dilakukan serta sukses story kelompok tani Karya Trans Mandiri, dilanjutkan dengan kunjungan pada usaha yang dilakukan kelompok tani Karya Trans Mandiri yaitu tanaman hultikultura dan peternakan kambing yang dikelola kelompok

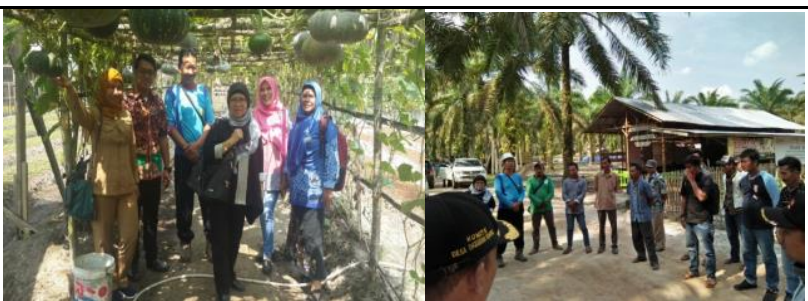

Setelah kunjungan pada usaha tanaman hultikultura, dilanjutkan kunjungan pada proses pembuatan kompos yang dilakukan kelompok tani Karya Trans Mandiri. Kelompok ini sudah memproduksi kompos 700 ton per bulan dan tanaman hultikultura. Tujuannya adalah agar kelompok tani Karya Muda melihat langsung semua tahapan proses produksi dan pengolahan kompos yang dilakukan kelompok tani KTM.

Proses produksi kompos yang diiikuti oleh

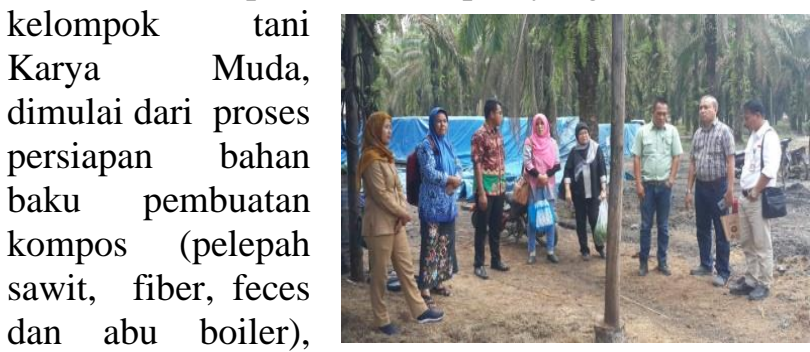
proses pencampuran dan pengadukan bahan kompos, proses fermentasi (pengomposan), proses pendinginan kompos, proses pengemasan sampai pada proses pengangkutan kompos kepada pemesan.

\section{Sarana dan Prasarana}

Salah satu kegiatan untuk mendukung program yang dilakukan adalah melengakapi sarana prasana pengolahan kompos pada kelompok tani Karya Muda. Sarana prasarana pengolahan kompos meliputi pembangunan rumah kompos, chopper, cultivator, mesin jahit karung, angkong dan bahan baku pembuatan kompos kurang lebih untuk 10 ton. Serah terima sarana prasana peralatan produksi kompos ini dilakukan oleh PetroCina International Jabung Ltd. kepada kelompok sasaran. Serah terima peralatan ini dilakukan pada lahan produksi kompos kelompok tani Karya Muda Desa Pandan Sejahtera Kecamatan Geragai. 


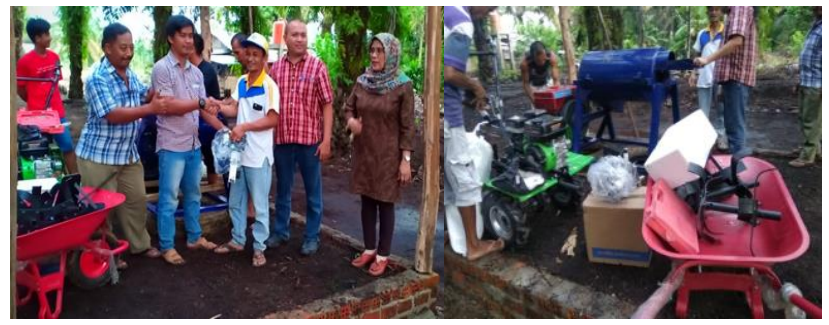

Sarana prasarana produksi kompos yang diserahkan kepada kelompok tani Karya Muda adalah satu unit rumah kompos, satu unit chopper, satu unit kultivator, sat1 unit angkong, satu unit mesin jahit karung dan dua unit terpal. Selain itu diserahkan bahan baku pembuatan kompos yaitu satu truk fiber dari limbah kelapa sawit dan satu truk abu boiler pabrik kelapa sawit serta bahan pendukung proses pembuatan kompos yaitu starter, dedak padi dan urea. Rincian masing-masing bantuan sarana prasarana pengolahan kompos adalah sebagai berikut :

\subsection{Rumah Kompos}

Rumah kompos merupakan salah satu bangunan yang penting dalam proses produksi kompos, terutama digunakan untuk proses pematangan dan pengemasan kompos. Pembuatan rumah kompos dilakukan pada lahan pembina kelompok Tani Karya Muda Desa Pandan Sejahtera dengan luas areal 0,25 ha. Pada lahan ini dibangun rumah kompos dengan ukuran 6 x 15 meter. Lokasi rumah kompos ini berada pada kebun pembina kelompok tani. Jika diperlukan pengembangan usaha, maka lahan disebelahnya bisa dipakai karena merupakan lahan anggota kelompok tani. Proses pembangunan rumah kompos dapat dilihat pada Gambar dibawah ini.

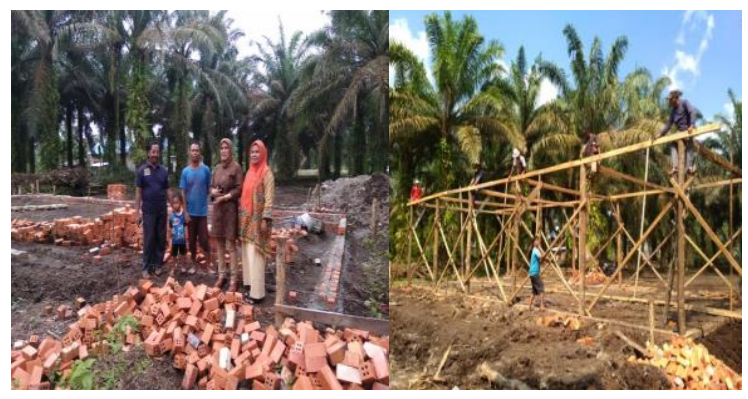

Proses pembangunan rumah kompos dilakukan secara gotong royang oleh kelompok tani
Karya Muda, sementara bahan bangunan pembuatan rumah kompos dilengkapi dari kegiatan ini melalui pendanaan PetroChina International Jabung Ltd. Pembuatan rumah kompos dilakukan secara gontong royong, ini bertujuan agar terbangun suasana keakrapan, rasa tanggung jawab dan rasa memiliki dari semua anggota kelompok terhadap bangunan yang ada. Selain itu untuk memotivasi agar usaha ini berjalan dengan baik.

\subsection{Chopper}

Chopper merupakan salah satu peralatan yang berperan penting dalam proses produksi dan pengolahan kompos berbahan dasar limbah kelapa sawit. Chopper ini digunakan terutama untuk mencacah pelepah sawit yang digunakan sebagai bahan dasar pembuatan kompos sehingga ukuran pelepah menjadi halus. Pelepah yang sudah halus akan mempercepat proses pengomposan, dan kompos yang dihasilkan lebih berkualitas (Gambar dibawah ini.)

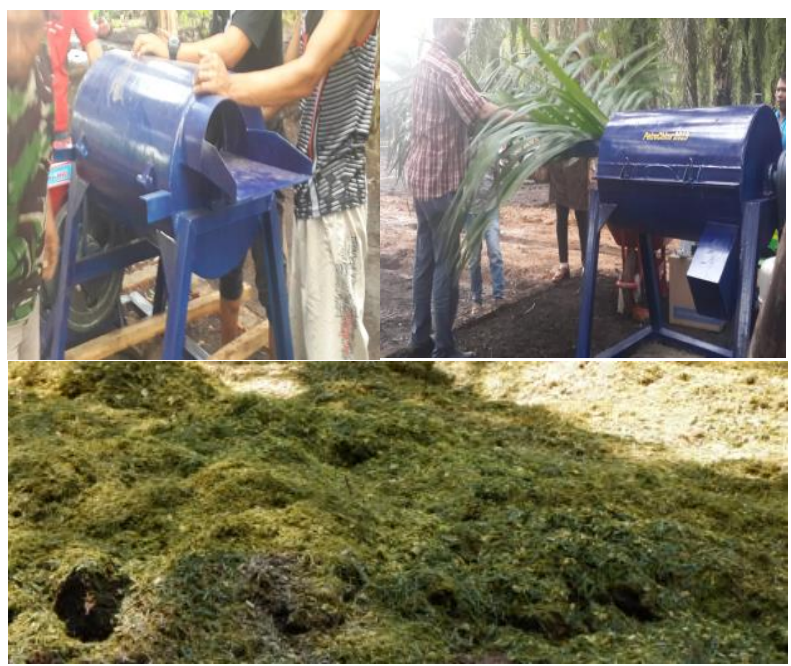

Gambar . Chopper Pencacah Pelepah Sawit

Chopper ini mampu mencacah pelepah sawit sebanyak 2 - 3 ton per hari dengan ukuran bahan yang dihasilkan kurang lebih 1- $2 \mathrm{~cm}$. Kondisi bahan yang lebih halus dalam proses pembuatan kompos akan meningkatkan luas permukaan sehingga lebih mudah mengalami proses dekomposisi atau pengomposan. 


\subsection{Cultivator}

Cultivator merupakan salah satu peralatan

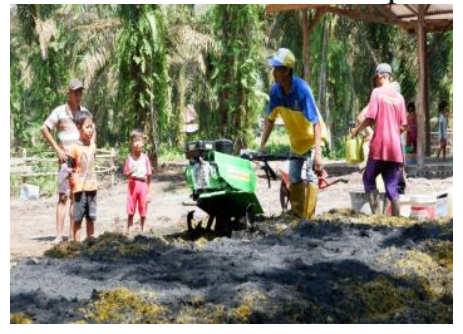
yang diberikan pada kelompok tani Karya Muda untuk mendukung usaha pengolahan kompos dari limbah ternak dan limbah kelapa sawit. Cultivator digunakan pada proses pengadukan kompos sebelum fermentasi (pengomposan) dan setelah fermentasi selesai yaitu proses pendinginan kompos sebelum dikemas, sehingga kompos yang dihasilkan lebih kerkualitas dan lebih cepat. Aktivitas penggunaan cultivator pada kelompok tani Karya Muda dalam pembuatan kompos dapat.

\subsection{Produksi Kompos}

Dalam rangka memperkuat dan memulai produksi kompos kelompok tani Karya Muda, maka tahap awal dilakukan proses pembuatan dan produksi kompos sebanyak 5 ton. Kegiatan ini memberi bantuan bahan baku berupa fiber satu truk, abu boiler satu truk, starter, dedak dan urea. Sementara untuk bahan baku feces sapi dan pelepah kelapa sawit adalah swadaya kelompok tani Karya Muda sendiri. Bahan baku yang tersedia pada kelompok tani Karya Muda bisa memperoduksi kompos sekitar 10 ton.

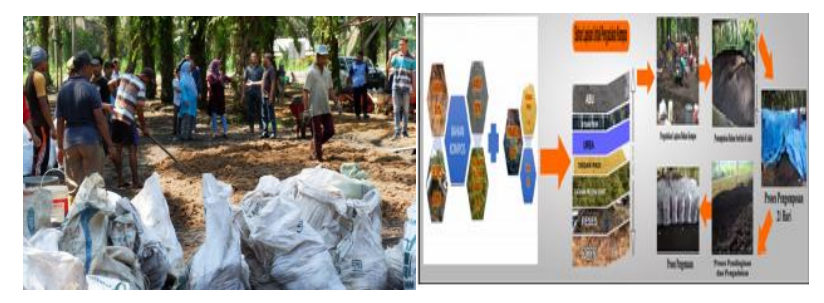

Proses pembuatan kompos bisa dilakukan dengan dua cara yaitu;

1. Sistem pencampuran awal yaitu pencampuran semua bahan pada awal proses pengomposan, setelah itu baru dilakukan penumpukan (pelapisan) sampai ketinggian 1 - 1,5 meter. Selanjutnya ditutup dengan terpal untuk proses pengomposan selama 21 hari.

2. Sistem lapis yaitu masing-masing bahan kompos dilapis mulai dari bahan yang paling banyak pemakaiannya sampai ke bahan yang paling sedikit. Satu lapisan maksimal $15 \mathrm{~cm}$, setelah itu bisa dibuat lapisan berikutnya dibagian atas lapisan pertama, sehingga bisa dibuat sampai ketinggian lapisan 1- 1.5 meter.

\subsection{Monitoring dan Evaluasi}

Monitoring dan evaluasi dilakukan dengan dua sistem yaitu pertama dilakukan setelah pelatihan selesai dengan menggunakan quisoner terhadap semua peserta, dan kedua dengan cara diskusi dengan kelompok di akhir kegiatan.

\begin{tabular}{lr}
\multicolumn{1}{c}{ Kegiatan } \\
monitoring & dan \\
evaluasi & pada
\end{tabular}

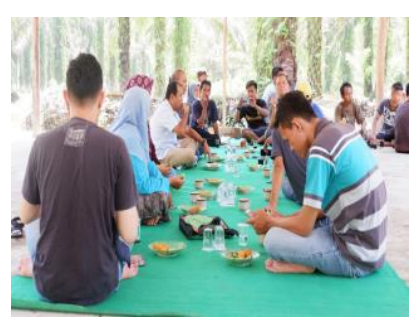

kelompok tani Karya Muda didapatkan beberapa hasil yaitu : 1) anggota kelompok sudah bisa menerapkan teknologi tepat guna (TTG) pengolahan kompos dari limbah ternak dan kelapa sawit. 2) direncanakan produksi kompos tahap awal sebanyak 10 - 20 ton per bulan, 3) perlu dicari pembeli produk kompos yang rutin untuk menjamin pemasaran, 4) Usaha kelompok akan dikembangkan kearah integrated farming system dengan melengkapi beberapa sarana dan prasarana pendukung, sehingga menjadi pusat percontohan dan pelatihan.

\section{KESIMPULAN}

Kegiatan pelatihan teknis pengolahan limbah dapat meningkatkan pengetahuan, wawasan dan pengalaman dalam proses pengolahan limbah ternak dan kelapa sawit yang ada disekitar petani peternak bernilai tambah (value added). Direncanakan produksi kompos tahap awal 10-20 ton per bulan

\section{UCAPAN TERIMAKASIH}

Ucapan terimakasih disampaikan kepada PetroChina International Jabung Ltd yang telah mendanai kegiatan pemberdayaan kelompok tani dalam pengembangan usaha kompos di Kecamatan Geragai, Dinas Perkebunan dan Peternakan Kabupaten Tanjung Jabung Timur, Taman Teknologi Pertanian yang sudah menyediaakan tempat pelatihan, Universitas Jambi sebagai nara 
sumber kegiatan pelatihan danKoperasi Sukamaju Desa Kota Baru Kecamatan Geragai. 